\title{
TINJAUAN TEOLOGIS MENGENAI MESIANIS DALAM PENTATEUKH
}

\author{
Oleh : Dr. Luhut P. Lumban Gaol, M.Th \\ Sekretaris SPMI
}

\begin{abstract}
ABSTRAK
Kitab Pentateukh merupakan kitab yang menceritakan mengenai karya Allah mengenai penciptaan dan salah satu karya Allah yang istimewa yakni ketika Allah menciptakan manusia segambar dan serupa dengan Allah. Pada saat Allah menciptakan manusia di mana manusia dalam keadaan kudus dan suci. Dosa tidak ada dalam diri manusia, namun karena manusia ketika dicobai oleh Iblis dan manusia ingin sama dengan Allah, sehingga akhirnya manusia jatuh dalam dosa dan akhirnya manusia kehilangan kemuliaan dan kekudusan Allah. Memang kata Mesias sendiri tidak terdapat dalam Pentateukh (kitab Kejadian sampai Ulangan) berhubungan dengan penjelasan secara langsung, tetapi ada beberapa penjelasan yang dapat membuktikan bahwa gambaran tersebut mengarah kepada Mesias sebagai penyelamat umat manusia. Kata yang dipakai untuk menjelaskan istilah yang berhubungan dengan Mesias adalah dalam kaitan dengan kata yang diterjemahkan dalam bahasa Ibrani dan kata tersebut sebagai makna kata kerja jv^m* (māšah). Kata ini dapat diartikan mengurapi, menuangkan cairan; sedang mengurapi.
\end{abstract}

\section{Kata Kunci : Teologis, Mesianis, Pentateukh}




\section{A. PENDAHULUAN}

Pentateukh merupakan awal dari segala permulaan yang di mulai dari penciptaan manusia dan keberadaan manusia selama ada di bumi. Ada suatu problema yang terjadi dalam diri manusia, sehingga ada sebuah penyataan terhadap nubuatan yang berhubungan dengan Mesias sebagai penggenapan dari penyelamatan manusia. Dalam tinjauan ini memberikan suatu penjelasan terhadap Mesias tentang kedatangan-Nya ke dalam dunia ini.

Ada tujuan yang berhubungan dengan manusia dalam kaitan dengan penyelamatan, tetapi lebih dari pada ini ingin memberikan suatu penjelasan yang lebih spesifik terhadap pembuktian terhadap nubuatan Mesianis dalam kitab Pentateukh sebagai dasar dalam memberikan penjelasan yang mengarahkan kepada pemahaman orang Yahudi. Pembuktian ini adalah sebagai dasar kebenaran yang memberikan pemahaman yang dapat dilihat dari sejarah perjalanan waktu. Sebab dengan kepercayaan orang Yahudi terhadap Pentateukh adalah sebagai acuan terhadap pemahaman mereka dalam penggenapan nubuatan tersebut.

\section{B. DASAR PEMAHAMAN MESIAS DALAM PENTATAEUKH}

Karya Allah bagi dunia ini dinyatakan dengan tujuan supaya apa yang menjadi rencana-Nya itu dapat direalisasikan, sehingga Dia memilih manusia sebagai wakil-Nya di bumi. Allah bekerja dengan memberikan segala sesuatu yang berhubungan dengan kepentingan manusia yang sudah ditetapkan-Nya. Rencana yang diberikan Allah itu pada dasarnya adalah indah dan memberikan kepercayaan kepada mereka untuk mengusahakan segala kepercayaan itu dengan baik. Hal ini sudah dipersiapkan Allah dengan memberikan segala keperluan untuk kebutuhan dalam mencukupi apa yang menjadi kebutuhan mereka. Lima kitab Perjanjian mengukapkan beberapa bagian yang menjelaskan sekitar Mesias yang akan datang dan merupakan penyataan sebagai bukti peran Allah dalam penyelamatan manusia. Dalam hal ini dihubungkan dengan akibat dosa yang telah dilakukan oleh manusia berhubungan dengan pengaruh ular tersebut. Karena 
manusia tidak merasa puas dan ingin menempatkan diri mereka sama seperti Allah, sebab pengaruh ular yang ingin membuat mereka jatuh. Ular menggoda mereka sehingga mereka tergoda, dan dengan perbuatan tersebut mereka berada dalam posisi yang sudah berbeda. ${ }^{1}$ Dengan posisi yang sudah dalam keadaan berdosa, maka tidak ada lagi hubungan yang dapat dipertahankan dan juga tidak ada lagi tempat bagi mereka di taman Eden, selain harus dikeluarkan.

\section{Arti Kata Mesias}

Memang kata Mesias sendiri tidak terdapat dalam Pentateukh (kitab Kejadian sampai Ulangan) berhubungan dengan penjelasan secara langsung, tetapi ada beberapa penjelasan yang dapat membuktikan bahwa gambaran tersebut mengarah kepada Mesias sebagai penyelamat umat manusia. Gambaran ini diberikan untuk memberikan sebuah pengertian yang menjelaskan tentang pemahaman konsep Mesias tersebut dengan tujuan untuk menjelaskan masa penggenapannya, maka manusia dapat memahami bahwa penggenapan tersebut mengarah kepada suatu kenyataan yang riil dan sesuai dengan gambaran tersebut.

Kata yang dipakai untuk menjelaskan istilah yang berhubungan dengan Mesias adalah dalam kaitan dengan kata yang diterjemahkan dalam bahasa Ibrani dan kata tersebut sebagai makna kata kerja jv^ $\mathrm{m}^{*}$ (māšah). Kata ini dapat diartikan mengurapi, menuangkan cairan; sedang mengurapi, ${ }^{2}$ menyebarkan suatu cairan (minyak, pengolesan) di atas roti-roti kecil dengan minyak (Kel. 29:2); mengurapi tiang (Kej. 31:13); mengurapi binatang-binatang korban (Kej. 29:36). ${ }^{3}$ Pengurapan ini dilakukan berhubungan dengan tujuan supaya semua yang ada dalam kaitan dengan benda itu adalah kudus, baik itu berhubungan dengan tempat dan juga persembahan.

\footnotetext{
${ }^{1}$ Encarta ${ }^{\circledR}$ Reference Library 2003. ( 1993-2002 Microsoft Corporation. All rights reserved. CD-ROM.

${ }^{2}$ John N. Oswalt, "jv^m," dalam New International Dictionary of Old Testament Theology \& Exegesis, peny., Willem A. VanGemeren (Carlisle, UK: Paternoster Publishing, 1997), hlm. 2:1123.

${ }^{3}$ William L. Holladay, "jv^m*," dalam A Concise Hebrew and Aramic Lexicon of the Old Testament (Grand Rapids: William B Eerdmans Publishing Company, 1988), hlm. 218.
} 
Pengurapan juga dilakukan bagi pribadi yang berkaitan dengan mereka yang berhubungan dengan panggilan sebagai wakil Allah. Gagasan mengenai pengurapan seseorang untuk suatu misi secara khusus muncul beberapa kali, terutama bagi raja-raja dan imam-imam (Im. 4:3). ${ }^{4}$ Hal ini berhubungan juga mengurapi seseorang, seperti: untuk raja (bnd. 1 Raj. 1:34), imam (Kel. 28:41) dan nabi (1 Raj. 19:16). ${ }^{5}$ Sedangkan kata yang digunakan dalam bahasa Inggris diperoleh dari Ibrani mashiah, artinya "yang diurapi."6 Sejalan dengan itu kata ini dapat dihubungkan dengan pengertian yang mengarah kepada suatu posisi dalam pemerintahan. Sebagai penjelasan jika diartikan secara literal, maka maknanya menempatkan kata tersebut sebagai bagian dari yang ditahbiskan sebagai pemimpin yang telah dilantik. Dalam sumber kemudiannya yang dapat ditemukan "yang diurapi" tentu dengan kata sandang, dan juga "Mesias ku" dan "Mesias dari kebajikan." Tetapi ada juga Mesias tanpa artikel dan adalah hampir satu dengan nama diri. "Yang diurapi Tuhan" apakah hanya menggunakan figur-figur kerajaan, tetapi hanya para nabi Perjanjian Lama, dan juga (pada Qumran). ${ }^{7}$

Secara tidak langsung Perjanjian Lama juga memberikan gambaran yang berhubungan dengan Mesias tersebut, baik itu berhubungan dengan makna dan juga berhubungan dengan tindakan yang memberikan sebuah makna pada obyek yang akan diurapi. Perjanjian Lama ada dua akar kata yang berhubungan dengan "mengurapi," yaitu jvm (mšh) dan EWs (ṣ̂uk), menyatakan dua aspek tindakan yang berbeda tentang mengolesi atau menuangkan minyak bagi dirinya sendiri atau bagi orang lain.

Bentuk dari kata lebih sering digunakan, ada sebanyak 130 kali sedangkan untuk kata șhk hanya sebanyak 12 kali. Konotasi kata adalah dua kata yang terpisah. Kata mšh selalu mengacu pada upacara agama atau aktifitas formal yang dihubungkan dengan peresmian dan

${ }^{4}$ Donald Guthrie, Teologi Perjanjian Baru, pen., Jan S. Aritonang (Jakarta: BPK Gunung Mulia, 1999), hlm. 1:267.

${ }^{5}$ Holladay, "jv^m"," dalam A Concise Hebrew and Aramic Lexicon of the Old Testament, hlm. 218.

${ }^{6}$ Encarta ${ }^{\circledR}$ Reference Library 2003. (C) 1993-2002 Microsoft Corporation. All rights reserved. CD-ROM.

${ }^{7}$ A. S. van der Woude, "christos," dalam Theological Dictionary of the New Testament, peny., Geoffray W. Bromiley (Grand Rapids: William B. Eerdmans Publishing Company, t.t), hlm. 1:1325. 
dedikasi. șûk pada sisi lain, selalu mengacu pada pemakaian kosmetik dan barangkali juga berhubungan dengan pemakaian medis, penggunaan dari minyak dalam kehidupan sehari-hari. Satu kasus di mana dua akar kata dalam kalimat yang sama menggaris bawahi perbedaan ini, di dalam Keluaran 30:31, yang ditetapkan di mana bahwa minyak pengurapan disiapkan secara khusus miṣ̌̂a adalah tidak akan dituangkan yîsak di satu tubuh, yang artinya minyak khusus adalah tujuan-tujuan kosmetik yang untuk digunakan. ${ }^{8}$

Penyataan berkat Yakub kepada Yehuda yang menyatakan bahwa gemilang atas Israel yang diberikan kepada Yusuf pada jamannya, yang kemudian akan mengambil bentuk kerajaan di tengah-tengah Yehuda pada masa pemerintahan Daud. Pengertian hDyv! (š̂llōh), ${ }^{9}$ di dalam Kejadian 49:10 merupakan gelar Mesianik, yang berarti semacam yang mengadakan damai. Masa kejayaan dinasti Yehuda dicapai pada masa pemerintahan Daud dan hal tersebut mengantar ungkapan yang terakhir dari Kejadian 49:10 tersebut, yaitu Dia "yang berhak" atasnya, yang menunjuk kepada Mesianis (bnd. Mzm. 72:8-11). Dalam hal ini menggambarkan Yehuda sebagai pemenangan pertempuran yang seperti singa dan sebagai suku yang dinobatkan menduduki status raja yang berkuasa atas seluruh bangsa itu sejak jaman raja Yehuda yang pertama (bernama Daud). ${ }^{10}$

Perjalanan nubuatan Mesias dalam hubungan dengan waktu, maka Yehuda adalah jalan yang dipilih untuk menyatakan kedatangan melalui keturunan mereka. Yahuda adalah generasi yang memimpin dalam penjalanan untuk mendatangkan keturunan yang akan datang dari Mesias. Tongkat kerajaan tidak akan beranjak menunjukkan adanya generasi yang akan memimpin umat Allah yang disebut dengan mšh yang berhubungan dengan Kejadian 49:10, dimulai dari keturunan Yehuda yang bernama Daud (bnd. 1 Sam. 10:12-13), yang puncak tongkat kerajaan tersebut digenapi melalui nubuatan Mesias tersebut. Adanya estapet kerajaan, yang pada dasarnya kerajaan itu adalah milik Mesias sendiri, tetapi Daud sebagai lambang dari pemerintahan kerajaan yang akan datang tersebut. Kata šîlōh dapat diartikan: "yang

\footnotetext{
${ }^{8}$ Oswalt, "hyv^m"," dalam New International Dictionary of Old Testament Theology and Exegesis, 2:1123-1124.

9John Joseph Owens, "Genesis," dalam Analytical Key to the Old Testament (Grand Rapids: Baker Book House, 1989), Genesis - Joshua, hlm. 1:228.

${ }^{10}$ Gleason L. Archer, Hal-hal yang Sulit dalam Alkitab, peny., Tjuk Subandiah Kaihatu, pen., Suhadi Yeremia (Malang: Gandum Mas, 2004), hlm. 172.
} 
kepunyaan dia," "ia itu adalah siapa punya." ${ }^{11}$ Konteks ini menjelaskan bahwa ada pribadi yang memiliki kepunyaannya, berubungan dengan umatnya. Kata mšh dalam dalam hubungan dengan konteks ini adalah hubungan dengan pribadi yang diurapi, jadi yang diurapi tersebut adalah yang berhak memiliki umat kepunyaan-Nya dan Dia adalah yang berkuasa atas segala bangsa-bangsa (Kej. 49:10d).

Selain itu kata masa māšhah juga digunakan dalam bentuk lain yang berhubungan dengan pelantikan bagi mereka yang memiliki posisi atau kedudukan yang berhubungan dengan pemimpin. Kata ini memang berhubungan dengan pengurapan yang biasa dilakukan untuk pelantikan yang memakai sarana yang dihubungkan dengan minyak pengurapan. Pada tingkatan lain kata ini digunakan pengurapan dalam pelantikan jabatan pemimpin, tindakan yang berhubungan dengan pencurahan minyak bagi seorang pribadi pemimpin. ${ }^{12}$ Memang kata tersebut tidak selalu berhubungan dengan Mesias, sebab kata ini bisa juga dihubungkan dengan pengurapan yang bisa dipakai secara umum. Pengurapan dilakukan dalam arti sacaramental-bayangan bila raja baru dinobatkan memangku jabatannya. Demikian pula Samuel meminyaki Saul (bnd. 1 Sam. 10:1), Elia meminyaki Yehu (2 Raj. 9:3) dan Yoyada meminyaki Yoas (2 Raj. 11:12). Dan juga bisa pengolesan berhubungan dengan memberikan minyak pada luka yang memar (bnd. Yak. 5:14). ${ }^{13}$

Dapat dibuktikan bahwa kata māšhah adalah kata yang sangat sering digunakan dalam hubungan dengan pelantikan dan juga berhubungan dengan keagamaan. Kata ini sudah menjadi populer dalam penggunaannya di dalam Pentateukh sebagai bentuk yang sangat sakral pada masa itu, dan kemudian sebagai realisasi dari gambaran Mesianik. Tidak dapat dipungkiri bahwa ungkapan ini bisa juga berhubungan dengan kepemimpinan berhubungan dengan mereka yang punya kedudukan sebagai imam atau pemimpin rohani. Pada zaman Perjanjian Lama, raja-raja dan imam diurapi (Kel. 29:7; Im. 4:3; Hak.

\footnotetext{
${ }^{11}$ Brown, Driver dan Briggs, "h[yv!," dalam The Brown-Driver-Briggs Hebrew and English Lexicon (Peabody: Hendrickson Publisher Inc, 1996), hlm. 1010.

${ }^{12}$ Harris, Theological Word Book of the Old Testament, hlm. 2:530.

${ }^{13}$ R. K. Harrison, "Minyak Wangi," dalam Ensiklopedi Alkitab Masa Kini, peny., H. A. Oppusunggu., pen., Andar Lumbantobing (Jakarta: Yayasan Komunikasi Bina Kaih/OMF, 2002), hlm. 2:87.
} 
9:8; 1 Sam. 9:16; 10:1; 2 Sam. 19:10). ${ }^{14}$ Tindakan untuk melakukan pengurapan ini biasanya dilakukan oleh mereka yang memiliki hubungan dengan jabatan kerohanian dalam melantik orang, baik mereka sebagai imam ataupun nabi. Berarti ini adalah teologi yang sangat penting untuk kata māšhah, mengurapi bagi pribadi atau pada obyek yang diindikasikan sebagai pemisahan pada otoritas dari pertolongan Allah. Harun diurapi oleh Musa "pada pengudusannya," Bil. 8:12; bnd. Kel. 29:36 berhubungan dengan altar], ${ }^{15}$ dan juga pengurapan yang dilakukan oleh Musa yang menempatkan Harun sebagai imam besar sekaligus juga pengurapan yang dilakukan kepada anaknya. Namun telah jelas bahwa pemilihan seseorang oleh tua-tua untuk menjadi raja dengan mengurapinya merupakan suatu prasyarat yang menyatakan kehendak Allah tentang seseorang yang akan menjadi raja di masa depan. ${ }^{16}$

Dengan cara yang sama, penyucian-penyucian dan pengurapan adalah sering dihubungkan dengan acuan untuk peresmian tempat peribadatan dan keimaman (Kel. 29:36; 40:9-11,13,15; Im. 8:10-12,30; Bil. 7:1). ${ }^{17}$ Penyucian ini merupakan hal yang sangat penting bagi Israel dalam hubungan dengan kekudusan Allah, sebab orang yang dipilih Allah dalam kaitan dengan pelayanan harus memiliki sudah sifat kekudusan dan hal itu harus dinyatakan melalui penyucian, sehingga punya kelayakan untuk dapat melayani. Penggunaan kata "suci" dengan "minyak pengurapan" (Kel. 30:35,31; 37:29), dengan alasan pengurapan mereka, pada orang atau obyek ini adalah tidak lagi biasa, setelah itu baru melakukan kekudusan yang dari Allah (lih. Im. 8:12,30; $21: 12){ }^{18}$

Penggunaan istilah Mesias ini terus berkembang dalam penggunaannya, sekalipun dengan berbagai perubahan bahasa, tetapi padan kata serta maknanya selalu terus mengalami perkembangan dalam penggunaannya. Dalam perkembangan bahasa yang dijadikan sebagai bahasa pengantar orang Israel, secara khusus Yahudi penggunaan bahasa mereka semakin mengalami perkembangan.

\footnotetext{
${ }^{14}$ Louis Berkhof, Teologi Sistematika: Doktrin Kristus, peny., Hudiyekti P dan Henki, pen., Yudha Thianto (Surabaya: Momentum, 2002), hlm. 3:24.

${ }^{15}$ Harris, Theological Word Book, hlm. 2:530.

${ }^{16}$ Collin Brown, "Cpistovs," dalam The New International Dictionary of New Testament Theology (Grand Rapids: Zondervan Publishing House, 1986), hlm. 1:121.

${ }^{17}$ Oswalt, "hyv^m*," dalam New International Dictionary, hlm. 2:1124.

${ }^{18}$ Ibid.
} 
Sebagai contoh jika melihat dari perkembangannya, awal pengunaan bahasa Ibani sampai perkembangannya sekarang bahwa konsep Mesias itu masih memiliki makna yang sama. Pengunaan dalam bahasa lain juga memiliki makna yang sama, seperti dalam penggunaan bahasa Yunani. Penggunaan dalam bahasa Yunani Chritos adalah merupakan padan kata dalam bahasa Ibrani māšhiah. Seorang nabi, imam dan raja di dalam Perjanjian Lama, mereka diurapi dengan minyak. ${ }^{19}$ Nubuat ini mengacu kepada penggenapan eskatologis yang lebih besar dalam diri raja Mesianis, anak Daud. ${ }^{20}$ Penggenapan itu terus berjalan dari generasi ke generasi melalui keturunan dari penetapan yang dinyatakan Allah kepada Abraham.

\section{Perjanjian Mesias Kepada Adam}

Penjelasan yang paling menonjol tentang Mesias itu berhubungan dengan Kejadian 3:15, sebagai awal dari seluruh nubuatan yang dijanjikan Allah kepada keturunan perempuan. Dalam bagian ini secara tegas Allah memberikan keputusan yang memisahkan manusia dengan Allah dalam kaitan dengan permusuhan dan sebagai penyelamatan yang dilakukan Allah adalah dengan memberikan seorang yang akan menaklukkan kuasa dari Iblis tersebut. Rencana Allah bagi kepentingan manusia yang diungkapkan Allah yakni melalui penakluk, yaitu "benih wanita" yang dijanjikan akan menghancurkan Setan dan akan membawa keselamatan. ${ }^{21}$

Kontribusi dalam Kejadian 3:15 ini merupakan bagian yang sangat penting dalam kitab Kejadian dalam hubungan dengan kedatangan Mesias, sebab hal ini merupakan kunci yang berhubungan dengan karya yang dilakukan Allah dalam rencana penyelamatan tersebut. Janji kutukan yang diberikan Allah kepada ular itu dalam hubungan dengan meremukkan kepala hal ini merupakan bagian yang berkaitan dengan penempatan kepada rencana yang menunjuk kepada kedatangan Mesias

\footnotetext{
${ }^{19}$ M. E. W. Johnson, “Christ,” dalam Protestant Dictionary, peny., Charles H. H. Wright (Paternoster: Hodder and Stoghton, 1904), hlm. 102.

${ }^{20}$ George E. Ladd, A Theology of the New Testament (Grand Rapids: Wm. B. Eermans, 1981), hlm. 137.

${ }^{21}$ Chris Marantika, Masa Depan Dunia Ditinjau dari Sudut Alkitab: Eskatologi, peny., Mayan Marbun (Yogyakarta: Iman Press, 2004), hlm. 29.
} 
dan kemenangan yang dijamin. ${ }^{22}$ Satu sikap yang secara tegas yang langsung dinyatakan kepada ular dengan mengambil suatu keputusan yang tegas dalam memberikan pemisahan dan penyelamatan kepada manusia. Sehingga dalam konteks ini sangat jelas bahwa hubungan antara manusia dengan ular mengalami pemutusan total sebagai bukti adanya permusuhan.

\section{Perjanjian Mesias Kepada Abraham}

Abraham adalah konsep dasar Allah untuk memulai janji-Nya dengan cara memisahkannya dari sanak keluarga dan bangsanya, yang kemudian memberi perintah kepadanya untuk meninggalkan daerah asalnya. Perintah diberikan Tuhan kepada Abram: "Pergilah dari negerimu, dan dari keluargamu dan dari rumah ayahmu. Ke tanah yang akan $\mathrm{Ku}$ tunjukkan kepadamu; dan Aku akan membuat engkau menjadi bangsa yang besar, dan Aku akan memberkati engkau, dan membuat namamu; . . . .'(Kej. 12:1-3). Janji tentang berkat tersebut merupakan awal dari memulainya sebuah penyataan yang berkaitan dengan dasar berkat sebagai awal dari perjalanan untuk menjadikan sebuah bangsa yang besar dengan di mulai dari garis keturunan Abraham yang terus berkembang dan menjadi berkat bagi bangsa yang memberkatinya. Paling berpengaruh, janji kepada Abraham untuk memperjelas satu bangsa besar di mana semua orang di bumi harus diberkati, bagi yang memberkati dia dan benihnya tanah dari Kanaan (Kej. 12: 2,7). ${ }^{23}$ Siapa yang memberkatinya akan diberkati Allah dan siapa yang mengutuki dia akan dikutuki Allah, Abraham akan menjadi berkat bagi seluruh bangsa; dari padanyalah akan lahir keturunan perempuan itu. ${ }^{24}$

Jalan tentang hal ini juga dinyatakan melalui satu penjelasan dalam hubungan dengan sebuah penyataan yang membuat Abraham memiliki keyakinan dan hal ini dinyatakan kepadanya, bagaimana nantinya dalam pencapaian sebagai bangsa yang besar tersebut dapat dilihat dari

${ }^{22}$ Kyle M. Yates, "Kejadian," dalam Tafsiran Alkitab Wycliffe, peny., Charles F. Pfteffer dan Everett F. Harrison (Malang: Gandum Mas, 2004), Kejadian-Ruth, hlm. 1:40.

${ }^{23} \mathrm{~W}$. L. Walker, "Promise," dalam The International Standard Bible Encyclopaedia, peny., James Orr, John L. Nuelsen dan Edgar Y. Mullins (Grand Rapids: Wa. B. Eermands Publishing, 1981), Naarah-Socho, hlm. 4:2459.

${ }^{24}$ F. L. Baker, Sejarah Kerajaan Allah, pen., K. Siagian (Jakarta: BPK Gunung Mulia, 1996), hlm. 230. 
keyakinan bahwa Allah memberikan sebuah keyakinan tentang bagaimana Allah akan memberkati dan dia juga dapat menjadi berkat, jika mereka melakukan ketetapan yang sudah Allah berikan kepadanya (Kej. 15-17; 17:4-5).

Berkat keturunan yang diberikan kepada Abraham bukan hanya sekedar pemenuhan bumi saja, agar alam semesta ini memiliki makluk hidup seperti manusia. Sama halnya Tuhan berjanji untuk menyampaikan mengenai benih keturunan dari Hawa di dalam Kejadian 3, Dia memberikan janji tentang sebuah bangsa melalui keturunan dari Abraham. Yang membedakan kedua hal ini berhubungan dengan janji dan meguasai bumi beserta isinya, lebih kepada janji kepada Adam, sedangkan janji kepada Abraham lebih kepada keturunan yang akan datang untuk menyelamatkan manusia yang terhilang dan juga sebagai seorang yang harus disembah sebagai raja (Kej. 49:10).

\section{Perjanjian Tentang Mesias Kepada Musa}

Musa secara khusus dipanggil Allah untuk membawa bangsa Israel keluar dari Mesir, tetapi lebih dari pada itu Allah mau menepati janjinya kepada Abraham melalui Musa. Janji Allah itu di mulai dengan membawa bangsa Israel keluar dari tanah Mesir menuju tanah perjanjian yang sudah dijanjikan Allah. Perjanjian yang diberikan Allah kepada Musa berhubungan juga dengan realisasi dari rencana dalam penggenapan Mesias tersebut.

Kepercayaan akan datangnya Mesias tersebut jelas dinyatakan melalui keturunan Yehuda yang membawa kepada pemerintahan yang akan datang menjadi sempurna. Sekalipun pada dasarnya dengan perjalanan waktu banyak perubahan yang terjadi, tetapi tentang kedatangan Mesias tetap menjadi pengharapan bangsa Israel. Ini dapat dilihat di mana Israel menjadi terpecah dua, dengan membangun kerajaannya masing-masing. Dengan perbedaan tersebut tetap saja keduanya memiliki pengharapan tentan kedatangan seorang Mesias.

Pemisahan yang terjadi antara orang Samaria dengan Yahudi itu sudah terjadi begitu lama dan sampai sekarang pun orang Yahudi belum bersatu. Perpecahan itu terjadi karena tidak adanya kesatuan antara pemahaman mereka akan dasar kesatuan yang dinyatakan sebagai garis keturunan Abraham yang nantinya membawa garis 
keturunan yang datang untuk menyelamatkan umat tersebut. Bagitu juga orang Kristen dengan Yahudi tetap memiliki perbedaan yang sangat krusial dalam hubungan dengan Mesias, tetapi kedua dari bangsa yang pecah ini masih memiliki iman kepada kedatangan Mesias. Pengakuan iman orang-orang Samaria adalah: percaya akan Allah yang Esa dan Musa adalah nabinya, percaya akan hukumhukumnya dan gunung Gerizim adalah tempat yang telah ditetapkan oleh Allah untuk mempersembahkan korban. Dan ada dua unsur yang tidak kurang penting, yaitu tentang penghakiman dan kedatangan kembali Musa sebagai Taheb, yaitu pembaharuan atau Dia yang akan datang kembali. ${ }^{25}$ Ini memberikan suatu pembuktian bahwa iman akan pengharapan mereka masih tetap kepada pengharapan akan kedatang Mesias ditengah-tengah kehidupan mereka.

\section{TUJUAN KEDATANGAN MESIANIS}

Kedatangan manusia ke dalam dunia adalah untuk mengusahakan segala sesuatu yang sudah diciptakan Allah. Allah menginginkan manusia menjadi rekan dalam mengusahakan segala yang ada di bumi dengan menguasai dan mengusahakannya dengan baik, tetapi manusia gagal melakukannya. Dengan kegagalan ini, maka Allah melakukan sebuah tindakan agar ada sebuah perubahan dalam diri manusia yang sudah hidup dalam keterikatan dengan dosa. Berbagai tujuan yang dilakukan Mesias dalam wujud kasihnya kepada karya ciptaan-Nya, sehingga posisi manusia yang semula ada dalam ikatan dosa kini kembali menjadi pribadi yang sudah diperbaharuhi.

\section{Mengalahkan Dosa Maut}

Memahami konteks dalam hubungan dengan tindakan yang dilakukan dalam mengalahkan dosa yang telah dipersiapkan Allah jauh-jauh hari sebelum realisasi tersebut digenapi. Dalam kitab Kejadian 3:15 ungkapan kata: aku akan mengadakan permusuhan merupakan satu deklarasi yang menempatkan pemisahan antara ular

${ }^{25}$ C. E. Graham Swift, "Markus," dalam Tafsiran Alkitab Masa Kini, peny., Donald Gutrie dan lainnya, pen., Harun Hadiwjono (Jakarta: Yayasan Komunikasi Bina Kasih/OMF, 1996), Matius-Wahyu, hlm. 3:173. 
tersebut dengan manusia. Kata hb*ya回 ('êbāh) berarti dapat diterjemahkan "permusuhan," 26 hal ini dapat dihubungkan dengan dendam kesumat berdarah yang ada dalam lubuk hati manusia (bnd. Bil. 35:19, 20; Yeh. 25:15-17; 35:5,6). ${ }^{27}$ Permusuhan itu merupakan satu tindakan yang menempatkan pemisahan yang sangat nyata dalam kehidupan manusia dan ular tersebut, secara nyata hal ini semakin terus dinyatakan dalam penggenapan tersebut. Allah dengan sengaja menempatkan "permusuhan" di antara: pertama, "ular," yaitu setan; kedua, wanita. Allah juga merencanakan bahwa permusuhan itu akan berlanjut, keturunan setan dan keturunan wanita. ${ }^{28}$

Keberadaan manusia yang sudah jatuh dalam dosa, maka hukuman yang seharusnya didapatkan adalah kematian untuk selamanya. Dengan keberadaan tersebut maka Allah bertindak untuk menolong manusia dari kematian tersebut, yang memberikan pertolongan agar manusia dapat diselamatkan. Allah bertindak dalam keberadaan-Nya sebagai Allah dengan tujuan untuk menaklukkan kuasa dosa.

Satu penjelasan tentang mengapa manusia mencoba untuk membunuh ular-ular, dan mengapa ular mencoba untuk menggigit manusia; Kej. 2-3 adalah satu cerita yang menjelaskan situasi manusia saat ini. Penjelasan ini juga berargumentasi bahwa bentuk dari anak kalimat yang berakhir dengan "ular akan menggigit tumitnya" menunjukkan ketidaksukaan atas kemenangan manusia yang akhirnya pengupas kulit. $^{29}$

Tindakan yang dilakukan ular tersebut hanya sekedar melukai bagian tumit yang tidak dapat mematikan. Jika hal ini diperhadapkan dengan manusia akan mengalami sakit dan luka yang sakitnya tidak terlalu, sehingga sakit yang ditimbulkan tidak akan membawa kepada kematian pada manusia. Seperti wakil-wakil ular dan perempuan mewujudkan nasib dari benih mereka, dan bahwa nasib adalah

\footnotetext{
${ }^{26}$ Brown, Driver dan Briggs, "㠶“ya回," dalam The Brown-Driver-Briggs Hebrew, hlm. 33

${ }^{27}$ Yates, "Kejadian," dalam Tafsiran Alkitab Wycliffe, hlm. 40.

${ }^{28}$ Gultom, "Mesias menurut Pentataeukh," Pistis 1/2, hlm. 149.

${ }^{29}$ Gordon J. Wenham, "Genesis," dalam Word Biblical Commentary, peny., David H. Hubbard, Glenn W. Baker, John D. W. Watt (Dallas: Word Book Publisher, 2001), Genesis-Ruth, hlm. 1:80.
} 
menunjukkan nasib mereka juga. ${ }^{30}$ Sebagai akibat yang dialami oleh ular berbeda dari dampak yang telah dilakukannya kepada manusia, sehingga membuat ia menjadi bagian dari musuh manusia yang terus berjalan dari turun-temurun, sekalipun manusia mendapat penghukuman dari Allah, tetapi dampak yang paling besar akibat dosa adalah ular. Apa yang terjadi untuk ular-ular "menabur benih" di dalam masa depan jauh dapat dikatakan terjadi untuk ular juga. ${ }^{31}$ Kuasa yang dimiliki keturunan manusia yang menaklukkan dengan cara meremukkan kepalanya, sehingga sekalipun ia berusaha untuk menggigit manusia, tetapi kuasa tersebut tidak mampu memberikan luka yang berdampak untuk menaklukkan.

Pada sisi lain, ini harus diingat bahwa, ini adalah satu kutukan pada ular, bukan di umat manusia, dan sesuatu yang kurang dari satu seri akan diharapkan. Lagipula, ular dalam suatu situasi secara teknis lebih lemah, ular tersebut hanya mampu untuk menghantam tumit kaki manusia, sedang manusia dapat menghancurkan kepalanya. Kata kerja [Wv (śûp) jarang dipakai, dan kata ini sama artinya dalam kedua anak kalimat. Sebuah nubuat tentang pertikaian terus-menerus untuk saling memusnahkan antara keturunan perempuan dengan keturunan ular. ${ }^{32}$ Bila diterjemahkan sebagai "meremukkan," tampaknya cocok dengan ayat tentang kepala ular, namun kurang tepat untuk melukiskan serangan ular terhadap tumit manusia. Kata ini dapat juga diterjemahkan menjadi "bersembunyi menantikan," "membidik," "waspada." 33 Selain itu bersifat menentukan, cerita ini bukan hanya satu etiologi, cerita cocok persis yang menjelaskan mengapa ular-ular menjadi sangat tak enak; banyak unsur di dalamnya adalah sangat simbolis. $^{34}$

Bentuk dari gambaran ular ini berhubungan dengan takluknya kuasa yang ada dalam kuasa ular tersebut, sebagai bukti sekalipun ular tersebut memiliki kuasa tetapi Allah yang memiliki kuasa dengan meremukkan kepalanya sebagai bukti bahwa kuasa dari Iblis tersebut tidak mampu menaklukkan kuasa dari keturunan tersebut. Memang hal

\footnotetext{
${ }^{30}$ John H. Sailhamer, "Genesis," dalam The Expositor's Bible Commentary, peny., Frank H. Gaebelein (Grand Rapids: Zondervan Publishing House, 2000), Genesis-Deutoronomy, hlm. 1:55.

${ }^{31}$ Sailhamer, "Genesis," dalam The Expositor's Bible Commentary, hlm. 55.

${ }^{32}$ Yates, "Kejadian," dalam Tafsiran Alkitab Wycliffe, hlm. 1:40.

${ }^{33}$ Ibid.

${ }^{34}$ Wenham, "Genesis," dalam Word Biblical Commentary, hlm. 80.
} 
ini adalah bentuk dari tindakan Allah atas ular, karena tindakan yang dilakukannya untuk menyesatkan dan membuat manusia tersebut menjadi jatuh dalam pemberontakan kepada Allah. Dapat dijelaskan bahwa bahwa ular diakui sebagai menandakan dosa, kematian, dan kuasa dari kejahatan, itu menjadi jauh lebih mungkin kutukan, dan kejahatan, sehingga dengan umat manusia memenangkan dengan secepatnya. ${ }^{35}$

Dosa maut telah berkuasa atas manusia melalui tindakan yang dilakukan oleh ular, sehingga posisi manusia dalam keadaan yang terbelenggu. Allah melakukan tindakan-Nya dengan memberikan sebuah penyataan melalui nubuatan yang akan datang dengan memberikan perintah, bahwa ular akan mendapatkan kutukan, sekalipun ia adalah seekor binatang dan kuasanya yang ada di dalam dirinya, yaitu Iblis atau yang juga disebut Setan akan dikalahkan oleh seorang keturunan dari perempuan, yaitu dia adalah keturunan dari Yehuda itu sendiri. Tuhan mulai menunjuk Setan dan merinci hukuman untuk dosanya yang telah dilakukannya terhadap manusia. Ini adalah sesuai untuk memecahkan fakta bahwa Setan adalah penghasut, penggoda. Ia memikat perempuan dengan tujuan untuk menentang. Janji pertama dari seorang keturunan di dalam Alkitab masuk teguran Tuhan kepada Iblis di dalam Kejadian 3:15. Janji adalah secara teknis satu janji dari pembinasaan untuk ular, dan hanya janji kedua dari keselamatan untuk Adam dan Hawa dan keseluruhan umat. Mesias akan datang kemudian, kedua-duanya untuk menghancurkan Iblis dan untuk menyampaikan kepada manusia tentang kuasan-Nya, yang merupakan satu tema yang berlanjut ke dalam Perjanjian Baru.

Allah menyatakan suatu nubuatan dengan memberikan gambaran yang berhubungan dengan nubuatan dalam penaklukan kuasa Iblis tersebut. Memang tidak ada gambaran yang secara jelas dalam kitab Pentateukh memberikan penjelasan dalam penaklukan dosa maut, tetapi ada suatu kuasa yang diberikan dalam konteks Kejadian 3:15c, keturunannya akan meremukkan kepalamu. Penjelasan dalam konteks ini Allah berbicara kepada Iblis, di mana pada saatnya nanti keturunan dari Hawa akan meremukkan Iblis. Jika melihat dari penjelasan tersebut maka nyata bahwa kuasa tersebut akan takluk dan tidak memiliki kekuatan lagi.

\footnotetext{
${ }^{35}$ Wenham, "Genesis," dalam Word Biblical Commentary, hlm. 80.
} 
Kepala merupakan bagian organ tubuh yang paling penting dalam tubuh, sehingga segala aktivitas dalam itu dikontrol oleh unsur yang ada dalam kepala, artinya semua pergerakan dan tindakan, baik dalam berpikir atau merencanakan semua itu tidak terlepas dari kemampuan yang ada di dalam kepala, itu yang disebut dengan otak. Jika melihat dari seluruh aktivitas tubuh, maka kepala menyimpan banyak sel-sel yang berfungsi sesuai dengan fungsi yang ada di dalamnya, sehingga jika kepala mengalami luka maka hal itu akan sangat membahayakan, apalagi jika sampai kepala tersebut remuk, sudah pasti tidak memiliki kemampuan lagi.

\section{Menyelamatkan Manusia}

Penyelamatan merupakan tindakan yang memerlukan suatu pengorbanan yang menjadikan manusia menjadi orang yang terlepas dari ikatan maut. Jadi tentunya titik awal penyelamatan manusia dimulai dari pribadi Allah. ${ }^{36}$ Dengan dasar penyelamatan itu hanya bisa dilakukan bagi mereka yang sudah diubahkan menjadi pribadi yang sudah diperbaharui. Pada masa Pentateukh tindakan orang agar memiliki penyelamatan dari kutuk atau hukuman atas dosanya adalah dengan memberikan korban bakaran yang disesuaikan dengan tingkat kesalahan yang dilakukan. Kedatangan Musa dalam memimpin bangsa Israel bukan hanya sekedar menolong dan memimpin mereka keluar dari perbudakan, tetapi lebih kepada rencana Allah pada masa yang akan datang. Musa melakukan dalam memberitahukan kelepasan yang akan datang (Kel. 4:30-31; 6:8-9), dalam mengumumkan perintahperintah Allah kepada Israel pada malam penyelamatan, khususnya mengenai paskah (Kel. 11:1-3; 12:21, 28, 35-36; 13:3; dan 14:1). ${ }^{37}$

Terkait dengan konsep penebusan yang berhubungan dengan pemahaman Pentateukh. Dalam bahasa Ibrani kata rP\#k! (kipper) yang berarti: menyelubungi, menebus dosa/membayar utang dosa; menebus dosa/membayar utang para orang dan dosa oleh upacara-upacara

\footnotetext{
${ }^{36}$ Chris Marantika, Doktrin Keselamatan dan Kehidupan Rohani, peny., Mayan Marbun (Yogyakarta: Iman Press, 2002), hlm. 19.

${ }^{37}$ K. A. Kitchen, "Musa," dalam Ensiklopedi Alkitab Masa Kini, peny., H. A. Oppusunggu, pen., M. H. Simanungkalit (Jakarta: Yayasan Komunikasi Bina Kasih/OMF, 2002), hlm. 2:107.
} 
hukum. ${ }^{38}$ Dalam Imamat 16 penjelasan tentang penebusan ini menjelaskan juga tentang penebusan salah (16:19-20). Penjelasan dalam 16:20 ini kata $\Gamma P$ 国 $K^{\wedge} m$ ! (mikapper) dapat diterjemahkan "dari penebusan." 39 Dalam Imamat 16 ada beberapa ayat yang menggunakan kata rP\#k (kipper) dengan arti yang bisa diartikan sebagai "pendamaian" (Im. 16:16,17, 24,30,32,33,34). ${ }^{40}$ Ada juga penebusan yang dilakukan dengan melihat tingkat ekonomi yang ada pada mereka, sehingga tidak memberikan suatu patokan yang membatasi ketidakmampuan mereka. Bentuk korban bakaran adalah sarana yang dipakai pada masa itu, sehingga mereka kembali mendapatkan kelayakan, dengan komposisi yang sudah dikuduskan kembali melalui pengurapan atau korban bakaran yang diberikan.

\section{Mengembalikan Keberadaan Manusia}

Pada waktu manusia jatuh ke dalam dosa, maka posisi manusia pada masa itu sudah berada di luar taman Eden. Mereka diusir dan tidak layak menempati taman Eden tersebut, ini mau menjelaskan bahwa pada dasarnya Adam dan Hawa sudah tidak memiliki tempat lagi di tempat yang disediakan Allah, sehingga ia dikeluarkan. Manusia menempati tempat yang jauh berbeda, di mana mereka harus bekerja dengan keras untuk dapat mencukupi kebutuhan hidup mereka, bahkan harus bersusah payah untuk dapat mencukupi segala kebutuhan mereka (Kej. 318,19).

Kehidupan manusia menjadi sangat sulit dan banyak penderitaan yang harus dialaminya untuk mendapatkan segala kebutuhan untuk hidup. Ada banyak kesusahan yang harus dialami manusia dalam menjalani segala apapun yang dilakukannya dalam dunia ini dan Allah memberikan penghukuman yang begitu rupa kepada manusia. Porsi yang paling berat dialami oleh manusia adalah kehilangan kesempatan yang sudah diberikan Allah kepada mereka, yaitu hubungan yang harmonis dan juga kehilangan kekudusan yang berakibat fatal dan pada akhirnya membawa kepada maut.

\footnotetext{
${ }^{38}$ Brown, Driver dan Briggs, "ГР\#К!," dalam The Brown-Driver-Briggs Hebrew, hlm. 497.

${ }^{39}$ Owens, "Leviticus," dalam Analytical Key to the Old Testament, hlm. 1:504.

${ }^{40}$ Ibid., hlm. 520-507.
} 
Allah mengasihi umat-Nya dan Dia tidak menginginkan umat-Nya binasa, sehingga Allah berinisiatif untuk menyelamatkan manusia dari kutuk dosa yang membawa maut tersebut. Tujuan dari semua itu adalah untuk menempatkan manusia tersebut pada porsi semula, yaitu mengembalikan taman Eden yang sempat hilang dari pandangan manusia. Tindakan yang dilakukan Allah dalam konteks Perjanjian Lama adalah dengan "menutupi," kata ini menyangkut suatu upacara menutupi dosa (Im. 4:35; 10:17). ${ }^{41}$ Dalam koteks ayat ini menggunakan kata ryf!q=h!w+ (wehiqtîn), ${ }^{42}$ sebagai kata kerja dari kata dasar rfq (qātar), yang berarti "membakar." 43 Kata ini juga dapat dihubungkan dengan membakar korban dalam hubungan dengan penghapusan dosa yang telah dilakukan (Kel. 29:19). ${ }^{44}$

Peraturan upacara pengorbanan dalam Perjanjian Lama termasuk keharusan bagi pembawa persembahan untuk meletakkan tangannya ke atas hewan yang akan dipersembahkan sebagai korban. Ini berarti pengalihan dan penyerahan, dan secara tidak langsung berarti penggantian; sehingga hal ini benar-benar menyatakan penggantian korban bagi si pembawa korban. Kematian hewan ini menggantikan kematian yang seharusnya dialami orang yang mengorbankan hewan itu. Cara ini dengan jelas mengajarkan penggantian. ${ }^{45}$

Jadi dalam hubungan dengan konteks ini ada hubungan dengan pemurnian kehidupan manusia supaya mereka memiliki kehidupan yang kudus, sehingga ada posisi dalam pengembalian kepada tujuan dari semula yang di mana manusia pada awal mulanya adalah kudus.

Nubutan tentang kedatangan Mesias itu berkenaan dengan keselarasan yang di dalamnya berkaitan dengan pencapaian untuk memberikan posisi yang semula kepada manusia, sehingga mereka layak bertemu dengan Allah dan hidup bersama dengan, seperti pada waktu di taman Eden. Memang untuk mengembalikan ke tempat yang semula bukanlah hal yang mudah, sebab di dalamnya harus berhadapan

\footnotetext{
${ }^{41}$ Enns, The Moody HandBook of Theology, hlm. 1:402.

${ }^{42}$ Owens, "Leviticus," dalam Analytical Key to the Old Testament, hlm. 1:442.

${ }^{43}$ Brown, Driver dan Briggs, "rfq," dalam The Brown-Driver-Briggs Hebrew, hlm. 882 .

${ }^{44}$ Carl Reed, Diktat Kuliah: Kamus Sementara Bahasa Ibrani-Bahasa Indonesia, sem. IV, 2007, hlm. 98.

${ }^{45}$ Charles C. Ryrie, "Yesus Kristus Tuhan Kita," dalam Teologi Dasar: Panduan Populer Untuk Memahami Kebenaran Alkitab, pen., Ratri Kumudawati (Yogyakarta: Andi, 2004), bag., Keselamatan - Peristiwa-peristiwa Yang Akan Datang, hlm. 2:325.
} 
dengan pergumulan hidup yang harus diperhadapkan dengan pengorbanan untuk dapat menggantikan posisi maut yang seharusnya dialami oleh manusia. Tindakan yang dilakukan Allah adalah dengan mengadakan rekonsiliasi sebagai pembaharuan posisi manusia. Rekonsiliasi dilihat dari sudut pandang manusia. Manusia adalah orang yang telah keluar dari persekutuan karena dosa, dan manusia butuh direkonsiliasi untuk memperbaharuhi persekutuan ini. ${ }^{46}$

Rencana pengembalian ini membutuhkan proses waktu yang cukup panjang dan bahkan penggenapan tersebut dapat terealisasi setelah masuk ribuan tahun. Berbicara secara logis bahwa hal ini menempatkan generasi yang cukup panjang untuk dapat mencapai pengembalian tersebut, sehingga banyak membuat penantian yang sangat panjang. Ini menjadikan Perjanjian Lama suatu bagian yang tidak dapat dipisahkan dari "sejarah persiapan" Allah untuk kedatangan Mesias. ${ }^{47}$ Jika melihat hal itu bukan berarti Allah tidak menepati janjinya, sebab penyelamatan Allah tetap berlaku bagi mereka yang hidup dalam masa Perjanjian Lama. Korelasi penyelamatan itu diberlakukan kepada mereka juga yang berada di dalam Perjanjian Lama, sekalipun karya penyelamatan yang dilakukan Mesias itu baru dapat digenapai pada masa Perjanjian Baru.

\section{GARIS KETURUNAN MESIANIS}

Setiap manusia yang lahir dalam dunia ini pasti memiliki keturunan, sebagai bukti bahwa mereka memiliki silsilah kelahiran. Manusia adalah makluk yang ada karena adanya suatu hubungan yang menjadikan manusia tersebut ada. Dalam hal ini Mesias yang dinyatakan sebagai manusia juga memiliki hubungan dengan kelahiran dan juga memiliki keluarga. Kehidupannya dinyatakan melalui sebuah silisilah untuk membuktikan bahwa Dia pernah ada di dalam dunia ini dan juga memiliki karakter dan layaknya melakukan aktivitas yang berhubungan dengan kemanusiaan yang ada di dunia ini.

\footnotetext{
${ }^{46}$ Enns, The Moody Handbook of Theology, hlm. 1:402.

${ }^{47}$ Hill dan Walton, Survei Perjanjian Lama, hlm. 713, 714.
} 


\section{Lahir Dari Keturunan Manusia}

Kelahiran tidak bisa dihindarkan dari kehidupan manusia, sebab dengan adanya kelahiran maka manusia akan semakin bertambah. Memang ada manusia yang tidak dilahirkan dengan perkecualian, yaitu Adam dan Hawa, sebab mereka adalah manusia yang pertama dan tidak mungkin dilahirkan, maka Allah berinisiatif untuk menciptakan mereka sebagai awal dari mulainya peradaban manusia yang dengan tujuan untuk menguasai segala yang ada di bumi ini sebagai kepercayaan yang diberikan Allah. Kelahiran mereka adalah sebagai awal dari memulainya garis keturunan yang menjadikan manusia berkembang semakin banyak dan memenuhi dari perintah Allah sendiri untuk memenuhi dunia ini (Kej. 1:28). Perintah itu merupakan awal dari kepercayaan Allah yang diberikan kepada manusia untuk memulai sebuah keluarga yang berkembang dan beranak cucu. Dia adalah benih keturunan Abraham, "putera dari Daud," "anak manusia," "anak-Ku," "hamba-Ku," "penasehat ajaib." "Allah yang berkuasa," "Bapa yang kekal" (Kej. 22:18). ${ }^{48}$

Dampak yang dialami oleh perempuan akan mengalami penderitaan yang sangat besar, ini adalah konsekuensi dari dosa yang dia lakukan. Tetapi di balik semua itu Allah punya rencana yang sangat besar dengan kehadiran keturunan sampai kepada kedatangan seorang Mesias dari keturunan tersebut. Memang penderitaan itu tidak akan pernah hilang dari perempuan sampai kepada generasi kegenerasi, ini berarti bahwa penderitaan tetap ada selama manusia itu melahirkan.

Abraham sebagai bapa orang beriman memiliki pengharapan yang sangat kuat tentang kedatangan sang Mesias. Harapan Mesias telah bergejolak di dalam hati Abraham dan di dalam pemikirannya, ia sebagai bangsa Israel atau dia membaca janji dari Mesias sebagai salah satu dari keturunan Abraham. Semula Allah sudah memberikan nubuatan dalam dengan menjelaskan tentang seorang akan lahir dari keturunan wanita tersebut (Kej. 3:15). Penjelasan ini dapat dihubungkan dengan perjanjian kepada Abraham dalam hubungan dengan memilih dan mengkhususkan dia sebagai umat Allah yang menjadi karya penggenapan dalam hubungan dengan garis keturunan yang dinyatakan dalam diri Abraham. Penjelasan secara tersirat disitu

${ }^{48}$ Merrill F. Unger, "Messiah," dalam Unger's Bible Dictionary (Chicago: Moody Press, 1976), hlm. 718. 
menggambarkan tentang keturunan yang berhubungan dengan ungkapan "semua bangsa di bumi akan mendapat berkat" (Kej. 12:3b), adalah merupakan penjelasan yang berhubungan dengan seorang pribadi yang dihubungkan dengan pembawa berkat. Dalam kitab Kejadian 49:10 semakin dipertegas dengan memberikan kepercayaan kepada keturunan Yehuda yang menjadi bagian dalam menempati kepercayaan dari benih tersebut. Artinya setiap konteks Alkitab semakin menyatakan dengan spesifik terhadap kelahiran yang dinantikan tersebut dan hal ini merupakan sebuah misteri yang semakin lama semakin memberikan suatu penjelasan yang semakin nyata. Ini dapat dilihat bahwa Allah terus mengembangkan arti pengertian tentang kelahiran seorang yang akan menyelamatkan manusia.

Pengembangan-pengembangan kemudian akan kepastian adalah penyebab beberapa kemunduran di dalam pengharapan. Abraham dan Sara sudah lanjut usia, tanpa seorang putera, dan dengan harapan yang semakin kecil dari keinginan mempunyai orang keturunan. Abraham dengan tidak bijaksana mengambil nasehat isterinya dan mempunyai seorang putera yang bernama Ismael dari perempuan Hagar, budak Sarai. Tetapi kemudian putera ini secepatnya telah diusir. Dalam suatu kesempatan Abraham rela memiliki isteri lain dari seorang hambanya, dengan begitu akan sangat membahayakan kepada anak yang sudah dijanjikan menjadi semakin tidak jelas menurut pemandangan Abraham dan Sara. Dalam perjalanan waktu Allah semakin menyatakan tentang kelahiran seorang Mesias tersebut melalui silsilah, yang secara umum dilahirkan melalui seorang perempuan (Kej. 3:15), kemudian adanya penjelasan yang lebih spesifik dengan memilih Abraham dengan mengkhususkan dia sebagai bangsa yang dipilih Allah dan mereka sebagai umat-Nya.

Berkaitan dengan janji yang dihubungkan dengan Kristus, apa yang Allah katakan kepada Musa di gunung Sinai yang berhubungan dengan Ulangan 18:18, Ia berjanji dalam nama Tuhan, bahwa pada dasarnya perlu datang seorang nabi besar yang berhubungan dengan Kejadian 3:15 tersebut. Hubungan yang dikaitkan dalam hal ini bukan berbicara berhubungan dengan posisi sebagai nabi dalam kaitan dengan jabatan atau pekerjaan-Nya, tetapi lebih kepada pribadi yang datang itu adalah merupakan sosok yang sama dalam kaitan dengan Mesias. Terbukti dari ayat-ayat seperti Keluaran 7:1 dan Ulangan 18:18 bahwa kata itu menunjukkan arti seorang yang datang dengan sebuah berita 
dari Allah kepada umat-Nya. ${ }^{49}$ Nabi tersebut dalam Ulangan 18:18 adalah penjelasan sebagai nabi yang datang dalam hubungan dengan nubuatan Kejadian 3:15 tersebut adalah satu pribadi yang akan membawa kepada satu tujuan dalam karya bagi penyelamatan manusia.

Setelah umat Israel dikeluarkan dari tanah perhambaan di Mesir dan dipimpin oleh Musa menuju ke Sinai, bangsa ini secara resmi diangkat oleh Tuhan Allah menjadi umat-Nya. Pengangkatan ini diresmikan dengan pendirian suatu perjanjian (Kel. 24:1-8). ${ }^{50}$ Perjanjian di Sinai itu berhubungan dengan bangsa Israel dengan tujuan untuk memberikan hukum kepada mereka supaya dapat hidup dengan aturan hukum yang diterima Musa pada saat di Sinai (Kej. 24:13). Dalam perjanjian ini sendiri ada muatan yang berhubungan darah sebagai perjanjian antara Tuhan dengan Israel. Makna darah itu adalah kematian yang menebus, dalam hal ini juga berhubungan tentang paskah yang merupakan kunci kepada seluruh sistem pengorbanan di Israel. $^{51}$ Kaitan pengorbanan ini dapat dihubungkan juga sebagai figuratif dari pengorbanan yang dilakukan oleh Mesias dalam penumpahan darah. Janji kemudian dibuktikan melalui karya dan penggenapan-Nya yang sudah direncanakan dengan sempurna dan pada waktunya akan digenapi.

Garis keturunan dimulai dari Adam dan Hawa, dan berjalan terus melalui fokus yang semakin menyempit sampai semua faktor penting dinyatakan. Garis Mesianik lebih dipersempit di mana berkat itu tidak akan mengalir melalui Ismail, tetapi melalui Yakub (Kej. 25:23; 28:13). Bilangan 24:17 menekankan bahwa seorang penguasa akan datang melalui keturunan Yakub. Ia akan menghancurkan musuh, serta "memiliki kekuasaan" (24:19; bnd. 9:10-13). ${ }^{52}$ Yerusalem yang akan datang itu adalah keturunan perempuan (Kej. 3:15); di dalam garis keturunan Set (Kej. 4:25); melalui Nuh (Kej. 6-9); keturunan Abraham (Kej. 12:1-3); lalu diteruskan melalui Ishak; terus sampai kepada Daud (2 Sam. 7:12,13). ${ }^{53}$ Tujuan dari penjelasan garis keturunan itu sangat penting untuk menunjukkan demontrasi Allah kepada manusia. Nubuat

\footnotetext{
${ }^{49}$ Berkhof, Teologi Sistematika, hlm. 3:127.

${ }^{50}$ Hadiwijono, Iman Kristen, hlm. 267.

${ }^{51}$ Hywel R. Jones, "Keluaran," dalam Tafsiran Alkitab Masa Kini, peny., Donald Guthrie, pen., P. S. Naipospos (Jakarta: Yayasan Komunikasi Bina Kasih/OMF, 1995), Kejadian-Ester, hlm. 1:174.

${ }^{52}$ Enns, The Moody Handbook of Theology, hlm. 1:266.

${ }^{53}$ Walvoord, Yesus Kristus Tuhan Kita, hlm. 73.
} 
yang berhubungan dengan kelahiran tersebut dinyatakan berkenaan dengan seorang anak dara yang akan melahirkan seorang anak laki-laki yang disebut Imanuel, yang berarti Allah beserta kita (Yes. 7:14) ${ }^{54}$ Dia datang sebagai terang dunia. Tuhan akan mengangkat dia dari tengahtengah mereka. Di dalam kelahirannya Dia harus tinggal dari antara salah satu bangsa, Dia tinggal di antara mereka. ${ }^{55}$

\section{Memiliki Sifat Manusia}

Sifat manusia adalah sebagai bukti bahwa Dia hidup dan bergaul dengan manusia dan juga kehidupannya sama dengan manusia serta memiliki keinginan sama dengan manusia. Sifat kemanusiaan itu sendiri digambarkan melalui keberadaannya dari kelahiran melalui seorang manusia, yaitu seorang perawan yang menjadi perantara terhadap lahirnya manusia yang kudus dan tidak memiliki celah.

Memang dalam Kejadian 3:15 ini tidak ada penjelasan yang berhubungan dengan keilahian-Nya dan hanya memberikan satu indikasi yang berhubungan dengan peremukan kepala dari si ular tersebut. Bahkan dalam penjelasan dalam bagian lain dalam Pentateukh secara riil tidak ada penjelasan dalam pembuktian bahwa Dia memiliki karakter sebagai Allah, tetapi lebih kepada keturunan yang berhubungan dengan kemanusiaan-Nya. Penjelasan kemanusiaan tersebut memberikan suatu indikasi akan keberadaan-Nya sama dengan kehidupan yang dialami oleh manusia pada umumnya dengan karakter yang nyata dalam dirinya yang tidak berbeda dengan manusia. Mesias diuraikan sebagai keturunan perempuan, sampai kepada nubuatannubuatan para nabi Perjanjian Lama di kemudian hari, Mesias dinyatakan sebagai nabi ${ }^{56}$ dalam penjelasan yang tidak terlalu jelas, tetapi bisa memberikan indikasi kepada karakter dalam diri-Nya yang berhubungan dengan penggenapan sebagai nabi dalam hubungan dengan Ulangan 18:18. Penyataan mengenai garis keturunan-Nya, hubungannya dengan Israel. ${ }^{57}$

${ }^{54}$ Enns, The Moody Handbook of Theology, hlm. 1:266.

${ }^{55}$ Bible Works, Matthew Henry, Commentary, ver., 5.0.033, Bible Works Software. Bible Works Versions Database Compiler.

${ }^{56}$ Walvoord, Yesus Kristus Tuhan Kita, hlm. 77.

${ }^{57}$ Ibid. 
Dapat dikatakan ia memiliki sifat manusia adalah berhubungan dengan nubuatan tentang kelahiran yang dinyatakan dalam Kejadian 3:15, di mana penjelasan tersebut mengarah kepada salah satu perwujudan dari kemanusiaan-Nya. Memang konteks dalam penjelasan tersebut tidak ada secara tertulis memberikan keterangan, tetapi jika dipahami ada bentuk tersirat yang menggambarkan berhubungan dengan keturunan dan ini adalah suatu bentuk biologis bahwa setiap orang yang lahir dari manusia, maka ia akan memiliki sifat manusia tersebut.

Gambaran dalam Kejadian 49:10 juga memberikan penjelasan yang berhubungan dengan tongkat kerajaan Yehuda tidak akan berlalu, ini memberikan indikasi bahwa adanya tongkat estafet yang terus berlangsung sampai kepada kerajaan Mesias sendiri. Dalam pemerintahan Israel secara khusus Yehuda kepemimpinan ini berhubungan dengan garis keturunan dan tidak mungkin dipimpin oleh keturunan dari keluarga lain apalagi berbeda bangsa. Memang raja pertama dari Israel adalah Saul dan dia adalah keturunan dari suku Benyamin, artinya secara estafet dari kepemimpinan ia bahwa seharusnya karakteristik seorang raja itu harus dimulai dari dia. Dalam pemerintahan sebagai raja di Israel yang menjadi pemimpin itu memang adalah Saul, tetapi dalam permasalahan yang terjadi bahwa dia menjadi raja itu bukan karena keinginan Allah, tetapi lebih karena keinginan orang Israel semata. Saul menjadi raja, tetapi dua kali ia ditolak menjadi raja (bnd. 1 Sam. 13:13-14; 15:10-13). ${ }^{58}$ Penjelasan konteks ini dapat membuktikan bahwa rencana pemerintahan yang diinginkan Allah itu sebenarnya bukan dari Saul, tetapi karena pada dasarnya hal ini lebih kepada keinginan Israel semata.

\section{E. TIPOLOGI MESIAS DALAM PENTATEUKH}

Sekalipun Perjanjian Lama, khususnya Pentateukh tidak langsung memberikan penjelasan tentang Mesias, tetapi Dia sendiri sudah memiliki sebutan yang berhubungan dengan jati diri-Nya. Ada beberapa penggunaan nama yang berhubungan dengan Pribadi tersebut, sehingga dapat dibuktikan bahwa Dia ada dan sudah ada sebelum

${ }^{58}$ David M. Howard, Kitab-kitab Sejarah dalam Perjanjian Lama (Malang: Gandum Mas, 2002), hlm. 177. 
segala sesuatu ada. Inkarnasi yang dilakukan-Nya sebagai manusia adalah sebagai bukti pengorbanan untuk memberikan pertolongan kepada manusia, agar ada kemenangan dalam diri mereka, sehingga terhindar dari hukuman maut.

Penggunaan yang berhubungan dengan Mesias dalam Pentateukh itu sudah ada disebutkan, yang berhubungan dengan jati diri-Nya sebagai pemelihara kepada umat-Nya. Ayat pertama dalam Alkitab yang menyatakan Mesias sebagai gembala dinyatakan oleh Yakub dalam Kejadian 48:15, ketika ia berkata, Allah itu sebagai Allah yang telah menjadi gembalaku selama hidupku sampai sekarang. ${ }^{59}$

Salah satu tipologi yang menarik dalam Pentateukh berhubungan dengan Melkisedek terkait dengan keberadaannya. Bila dikaitkan dengan perjumpaan dengan Melkisedek ada yang menjadi suatu persamaan terkait dengan karakter dan latar belakang kehidupannya, sekalipun nama yang dikaitkan dengan Mesias tidak ada hubungan dari maknanya. Dalam bahasa Ibrani Melkisedekh adalah qd\#x\#-yK!l=m^ (melek) dan (malkî- sedeq) terbagi menjadi dua suku kata dasar El\#m\# (melek) dan qd\#x\# (sedeq). ${ }^{60}$ Artinya melek ialah "raja" dan sedeq adalah benar dan dapat diartikan seperti dalam Ibrani 7:2 "raja kebenaran. ${ }^{61}$ Selain artinya "raja" kata ini dapat juga diartikan "dewa" yang menunjukkan kepada sesuatu hal yang tertinggi atau agung. ${ }^{62}$ Bila ia jumpa seorang raja yang tak dikenal Melkisedek, Abraham memberikan persembahan kepadanya dengan cara mempersembahkan perpuluhan dari hasil jarahan yang didapatkannya (Kej. 14:19). Ini Melkisedek adalah dikenali kemudiannya sebagai jenis dari Mesias, satu tema mengambil di dalam Mazmur 110, dan lebih secara penuh

${ }^{59}$ Elmer L. Towns, Nama-nama Allah: Mengungkapkan Rahasia Nama-nama Allah dalam Perjanjian Lama untuk Menolong Anda Mengenal Dia secara Lebih Mendalam, pen., Lee Roy Robertson dan Hariyono (Yogyakarta: Andi, 2003), hlm. 27.

${ }^{60}$ John McClintock dan James Strong, "Melchiz'edek," dalam Cyclopedia of Biblical Theological Ecclesiastical Literature (Grand Rapids: Baker Book House, 1981), Me-Nev, hlm. 6:57.

${ }^{61}$ F. F. Bruce, "Melkisedek," dalam Ensiklopedi Alkitab Masa Kini, peny., M. H. Simanungkalit, pen., H. A. Oppusunggu (Jakarta: Yayasan Komunikasi Bina Kasih, OMF, 2002), hlm. 2:50.

62Joseph Henry Thayer, "Melcisedevk," dalam Greek English Lexicon of the New Testament (New York: American Book Company, 1886), hlm. 397. 
menerangkan di dalam Ibrani 5:6,7,10. ${ }^{63}$ Mesias adalah Imam tertinggi yang sempurna yang mengambil figur dalam Melkisedek. ${ }^{64}$ Nama-Nya berarti: "Raja Keadilan," dan ia pun raja Salem, yakni raja damai, ${ }^{65}$ yang berarti juga "raja kebenaran" mengarahkan bahwa sebuah pemerintahan yang benar yang menghadirkan Allah. ${ }^{66}$

Melikisedek yang disebut "raja kebenaran," merupakan tipologi yang sangat unik, sebab memiliki karakteristik yang sangat mirip dengan Mesias. Ada berbagai gambaran dalam Alkitab yang memberikan penjelasan terhadap tipologi Melkisedek, hal ini dapat dilihat dalam perjalanan hubungan dalam sejarah (Kej. 14), sebuah kumpulan puisi (bnd. Mzm. 110). ${ }^{67}$

Nama ini sebenarnya mewakili yang baik, informasi yang kuno dari Kanaan, tentang pembentukan yang pararel Perjanjian Lama Adoni-zedek dan Abimelech; Akadian Milk-ilu (bnd. Perjanjian Lama Malchiel) dan Ilu-milku (bnd. Perjanjian Lama Elimelech); dan Ugaritic $m l k n \cup m$ (bnd. Perjanjian Lama Abinoam), Uilmlk, dan sdquil (bnd. Perjanjian Lama Zedekiah). Bagian-baian terjemahan yang masih meragukan tetapi biasanya member sebuah pengertian seperti nama raja Zedekia (dewa) atau Milki (dewa) adalah kebenaran atau raja kebenaran. ${ }^{68}$

Mesias dalam hubungan dengan Malaikat Yehovah merupakan hal yang sangat penting, terutama dalam hal karakteristik yang menjadi ciri khas yang dapat dilihat dari kehidupan-Nya, sebab ini merupakan sebuah nama yang berhubungan dalam Perjanjian Lama dan nama ini juga merupakan identitas yang mengarah kepada penampakan diri-Nya. Ketika Malaikat Tuhan atau Malaikat Yehovah berbicara kepada Hagar (Kej. 16:7-13), Dia dikenal sebagai Tuhan sendiri (ay. 13). Di dalam

\footnotetext{
${ }^{63}$ CD. Bob Deffinbaugh, "The Anticipation of Israel's Messiah," dalam Biblical Studies Press, hlm. 1996.

${ }^{64}$ William Gouge, Commentary on Hebrew (Grand Rapids: Kregel Publication, 1980), hlm. 482.

${ }^{65}$ Baker, Sejarah Kerajaan Allah, hlm. 116.

${ }^{66}$ Allen P. Ross, "Genesis," dalam The Bible Knowledge Commentary: Old Testament, peny., John F. Walvoord dan Roy B. Zuck (Wheaton: Victor Books, 1973), hlm. 798.

${ }^{67}$ Simon J. Kistimaler, "Melchizedek," dalam Who's Who in the Bible, peny., Paul D. Gardner (Grand Rapids: Zondervan Publishing House, 1995), hlm. 458.

${ }^{68}$ L. Hicks, "Melchizedek," dalam The Interpreter's Dictionary of the Bible: An Illustrated Encyclopedia, peny., George Arthur Buttrick (New York: Abingdon Press, 1963), hlm. 3:343.
} 
Kejadian 24:7, Yehovah diuraikan sebagai pengutus "malaikatnya." Hamba Abraham menyaksikan kenyataan di dalam Kejadian 24:40. Musa berbicara tentang Jehovah mengutus seorang malaikat untuk memimpin Israel (Bil. 20:16). ${ }^{69}$ Banyak penjelasan yang berhubungan dengan ungkapan Malaikat Tuhan sebagai penjelasan dari status dan identitas Mesias dari masa Perjanjian Lama, sebagai pembuktian keberadaan-Nya bersama sama dengan Allan Bapa dan Roh Kudus, sebagai Tritunggal Allah. Dia seringkali bertindak selaku utusan kepada berbagai orang (Kej. 16:7-14; 22:11-18; 31:11-13). Dia memberkati dan melindungi umat Israel (Kel. 14:19; 23:20; 2 Raj. 19:35). ${ }^{70}$ Dari semua ayat ini, dapat diketahui bahwa Mesias memiliki eksistensi yang tersendiri selama masa Perjanjian Lama dan bahwa Dia berulang-ulang berurusan dengan orang-orang Israel. ${ }^{71}$

Mesias adalah nabi seperti Musa yang merupakan seorang pemimpin yang membawa kelepasan kepada umat-Nya dan keduanya memiliki kemampuan yang berhubungan dengan kepemimpinan yang membawa keselamatan. Musa secara khusus membawa kelepasan kepada umat Israel, sedangkan Mesias mengarah kepada kelepasan kepada seluruh bangsa-bangsa yang ada di bumi (Kej. 49:10). Tuhan yang adalah undang-undang dan Musa merupakan salah satu yang menyampaikan undang-undang dan sampai mengantar Israel dari tanah Mesir ke tanah Kanaan, dan demikian juga Kristus, ${ }^{72}$ ia tidak hanya mengajar, tetapi juga memerintah.

Musa adalah pendiri dari satu peraturan baru oleh tanda-tanda dan perbuatan-perbuatan perkasa dan mengherankan, dan demikian juga dengan Mesias, di mana Dia membuktikan dirinya sebagai seorang seorang nabi datang dari Tuhan. Apakah Musa setia dalam perjalanan pelayanannya? Mesias adalah sangat setia; Musa sebagai pelayan, tetapi Yesus Kristus sebagai Putera. Bahwa Tuhan akan menaruh katakata-Nya di dalam mulut-Nya (Ul. 18:18). Sebagai yang paling unggul menerangkan dan mengajarkan kehendak Allah, perintah-perintah-Nya

${ }^{69}$ Walvoord, Yesus Kristus Tuhan Kita, hlm. 37.

${ }^{70}$ Charles C. Ryrie, ”Yesus Kristus Tuhan Kita," dalam Teologi Dasar: Panduan Populer untuk Memahami Kebenaran Alkitab, pen., Ratri Kumudawati (Yogyakarta: Andi, 2004), Prolegomena-Yesus Kristus Tuhan Kita, hlm. 1:325.

${ }^{11}$ Henry C. Thiessen, Teologi Sistematika (Malang: Gandum Mas, 2003),

${ }^{72}$ BibleWorks, Mattew Henry, Commentary, ver., 5.0.033, BibleWorks Software. BibleWorks Versions Database Compiler. 
dan kodrat-Nya dan dengan sifat-sifat yang demikian Musa-lah yang secara khas merupakah teladan dari semua nabi sejati di kemudian hari. Dalam hungan dengan penggenapan sampai pada saatnya datang seorang Mesias, yang bagi-Nya Musa merupakan perintis (Ul. 18:18; bnd. 3:22) dan yang tentang Dia semua nabi bersaksi (bnd. Kis. $10: 43) .^{73}$

\section{F. PEMAHAMAN YAHUDI TENTANG MESIANIS DALAM PENTATEUKH}

Israel merupakan bangsa yang pertama sekali menjadi rekan yang dipilih Allah sebagai umat-Nya dan sekaligus juga untuk membawa misi Allah dan tidak pernah Allah berubah dari pilihan-Nya kepada umat Israel sebagai bangsa pilihan (Kej. 48:4), sekalipun bangsa Israel sendiri tidak setia dan selalu melakukan pemberontakan kepada Allah. Jika melihat dalam perjalanan Israel menuju tanah Kanaan yang disebut tanah perjanjian, seharusnya waktu yang mereka tempuh untuk mencapai daerah tersebut tidak harus lama, sampai 40 tahun di padang gurun (Bil. 14:33; bnd. Am. 5:25). Apa yang mereka lakukan adalah karena pemberontakan kepada Allah yang sudah memimpin mereka dan mencukupkan segala kebutuhan yang diperlukan selama dalam perjalanan. Kekerasan mereka itulah yang membuat mereka berlamalama di padang gurun bahkan mereka disebut orang yang tegar tengkuk (Kel. 32:9; 33:3; Ul. 9:13; 10:16; 31:27; bnd. 2 Taw. 30:8).

Sekalipun dengan keberadaan Israel yang tegar tengkuk, tetapi Allah tetap senantiasa setia menantikan mereka dan dengan sabar selalu menuntun kepada jalan yang benar. Sekalipun dalam kehidupan mereka Allah selalu memberkati mereka, tetapi konsekuensi dari dosa yang mereka lakukan harus mendapat disiplin dari Allah melalui berbagai penghukuman. Allah sudah membuat perjanjian kepada mereka dengan menjadikannya sebagai bangsa yang besar, seperti janji yang diberikan kepada Abraham (Kej. 12:2, 3).

Tentu saja pengharapan yang begitu teguh tidak dapat dipisahkan dari pada perjanjian yang ada antara Yahweh dengan Israel "Aku akan mengangkat kamu menjadi umat-Ku dan Aku akan menjadi Allahmu, supaya kamu mengetahui bahwa Akulah Tuhan Allahmu" (Kel. 6:6).

${ }^{73}$ Kitchen, ”Musa," dalam Ensiklopedi Alkitab Masa Kini, hlm. 2:107. 
Berdasarkan perjanjian demikian itu, walaupun Israel dihajar oleh Tuhan, namun mereka tetap mengharapkan satu era keselamatan dan kebahagiaan yang sempurna, di mana Mesias itu akan menjadi tokoh utamanya. ${ }^{74}$ Pada dasarnya mereka memiliki pemahaman yang benar terhadap pengharapan Mesias pada masa yang akan datang untuk dapat menyelamatkan mereka dari berbagai penderitaan yang mereka alami.

Allah menetapkan Abrahan dengan mengkhususkan dia dengan memisahkannya dari sanak saudaranya untuk membentuk sebuah bangsa yang menjadi umat Allah. Dengan perjalanan waktu melalui keturunan Yakub Allah memilih Yehuda sebagai pemegang tongkat kerajaan pada masa yang akan datang (Kej. 18:10). Secara khusus dalam hubungan dengan Yehuda atau yang disebut juga Yahudi, di mana Allah memilih mereka sebagai keturunan yang dipilih Allah untuk membawa garis keturunan dari Mesias. Allah memberikan hak istimewa kepada mereka untuk menjadi bagian dalam membawa garis keturunan Mesias tersebut. Pilihan yang dilakukan Allah kepada mereka itu merupakan suatu anugerah yang sangat luar biasa, sebab pada dasarnya mereka tidak layak menyandang sebagai bangsa yang melahirkan seorang yang membawa penyelamat. Mesias dari suku Yehuda, akan memiliki "tongkat kerajaan." Raja memegang tongkat kerajaan pada waktu dia berbicara di hadapan publik; dan pada waktu ia duduk di atas takhta, maka dia meletakkan di antara kakinya serta mencondongkan kearah dirinya. Ayat ini juga menjelaskan bahwa Yehuda akan mempertahankan suatu garis keturunan "sampai Shiloh datang. ${ }^{75}$

Yahudi sendiri menantikan seorang Mesias sebagai penyelamat mereka dari dosa pemberontakan yang dilakukan oleh Adam dan Hawa. Sebagaimana orang Yahudi mengharapkan akan kedatangan seorang Mesias. Dasar pengharapan mereka adalah kelima kitab yang disebut dengan kitab Musa atau yang disebut dengan Pentateukh. Orang Yahudi sangat menjunjung tinggi kelima kitab Musa ini sebagai kitab yang memiliki wewenang, sehingga di dalamnya mereka mempercayai adanya seorang keturunan yang datang untuk membawa penyelamatan dalam hidup mereka dengan penantian. Asal usul ide Mesias erat sekali hubungannya dengan ide perjanjian antara Allah dengan Israel umat-Nya. Menjadi keyakinan bangsa Yahudi, bahwa

${ }^{74}$ Pardede, "Messias," dalam Yesus Kristus, Allah, Manusia Sejati, hlm. 47, 48.

${ }^{75}$ Enns, The Moody Handbook of Theology, hlm. 1:266. 
bangsa ini dipilih secara istimewa oleh Allah. ${ }^{76}$ Karena prakarsa dan kasihnya Allah menjalin hubungan dengan Israel dan disitulah Allah memilih umat secara unik, sehingga umat juga merasakan hubungan secara unik dengan Allah. Bangsa ini menyanggupkan diri memegang teguh pada hukum-hukum-Nya dan taat kepada-Nya (Kel. 24:1-8). Konsep pemahaman mereka tentang penyelamat itulah yang disebut dengan Mesias. Orang Yahudi mengharapkan kedatangan Mesias sebagai seorang tokoh yang dianggap sebagai pembaharu, pembebas, penyelamat dan pemberi damai.

\section{G. INTISARI NUBUATAN MESIAS DALAM PENTATEUKH}

Konsep Mesias merupakan satu pemahaman yang tidak berdiri sendiri dan bukan juga muncul dengan tanpa melihat korelasi dalam keberadaan manusia pada mulanya. Dalam hal ini bagaimana Pentateukh memberikan nubuatan yang mengarah kepada penyelamatan manusia melalui tindakannya dalam mengalahkan kuasa dari Ular tersebut. Jelas sekali dalam pembahasan ini Pentateukh bahwa Allah pada mulanya sudah memberikan suatu inisiatif untuk dapat membebaskan manusia dari belenggu yang mengikat mereka. Allah memberikan nubuatan bagaimana Mesias tersebut datang dengan kekuasaan-Nya dan memberikan kontribusi dalam penyelamatan bagi umat manusia.

Sekalipun dalam penjelasan yang diberikan Pentateukh, tetapi point yang menjelaskan nubuatan-Nya cukup mendalam dan dapat memberikan pengertian yang mengarah kepada kepastian terhadap kepastian tersebut. Subyek yang menjadi penyelamat juga mulai dinyatakan dalam kegiatan yang dilakukan dalam peribadatan yang berhubungan dengan korban persembahan, sekalipun dalam bentuknya masih sangat samar-samar.

Dalam penjelasan selanjutnya akan membahas berhubungan dengan Mesias dalam konsep Injil-injil dalam hubungannya dengan keberadaan selama ada dalam penggenapan tersebut. Bukti otentik yang menjelaskan bagaimana Injil-injil menjelaskan perasanan-Nya secara langsung yang dapat dilihat, baik itu berhubungan dengan kehidupan

${ }^{76}$ Darmawijaya, Gelar-gelar Yesus (Yogyakarta: Kanisius, 1991), hlm. 82. 
dan peranan-Nya dalam penyelamatan umat manusia. Pembahasan yang berhubungan dengan Injil-Injil sebagai landasan dalam kebenaran yang berhubungan dengan Mesias dengan memberikan suatu penjelasan melalui pemahaman yang ada dalam penggenapan tersebut. Bukti ini lebih kepada pemahaman yang memberikan penjelasan dalam hubungan dengan kondisi yang sedang terjadi pada masa itu.

\section{DAFTAR PUSTAKA}

Alkitab. Lembaga Alkitab Indonesia, 2015.

Archer, Gleason L. Hal-hal yang Sulit dalam Alkitab. Disunting oleh Tjuk Subandiah Kaihatu. Diterjemahkan oleh Suhadi Yeremia. Malang: Gandum Mas, 2004.

Baker, F. L. Sejarah Kerajaan Allah. Diterjemahkan oleh K. Siagian. Jakarta: BPK Gunung Mulia, 1996.

Berkhof, Louis. Teologi Sistematika: Doktrin Kristus. Jilid. 3. Disunting oleh Hudiyekti P dan Henki. Diterjemahkan oleh Yudha Thianto. Surabaya: Momentum, 2002.

BibleWorks, Mattew Henry. Commentary, ver., 5.0.033. BibleWorks Software. BibleWorks Versions Database Compiler.

Brown, Collin."Cpistovs." Dalam The New International Dictionary of New Testament Theology. Jilid. 1. Grand Rapids: Zondervan Publishing House, 1986.

Brown, Driver dan Briggs, "hПyv." Dalam The Brown-Driver-Briggs Hebrew and English Lexicon. Peabody: Hendrickson Publisher Inc, 1996.

Bruce, F. F. "Melkisedek." Dalam Ensiklopedi Alkitab Masa Kini. Jilid. 2. Disunting oleh M. H. Simanungkalit. Diterjemahkan oleh H. A. Oppusunggu. Jakarta: Yayasan Komunikasi Bina Kasih, OMF, 2002.

CD. Bob Deffinbaugh, "The Anticipation of Israel's Messiah.” Dalam Biblical Studies Press.

Darmawijaya. Gelar-gelar Yesus. Yogyakarta: Kanisius, 1991. 
Encarta® Reference Library 2003. (C) 1993-2002 Microsoft Corporation. All rights reserved. CD-ROM.

Gouge, William. Commentary on Hebrew. Grand Rapids: Kregel Publication, 1980.

Guthrie, Donald. Teologi Perjanjian Baru. Jilid. 1. Diterjemahkan oleh Jan S. Aritonang. Jakarta: BPK Gunung Mulia, 1999.

Harrison, R. K. "Minyak Wangi." Dalam Ensiklopedi Alkitab Masa Kini. Jilid. 2. Disunting oleh H. A. Oppusunggu. Diterjemahkan oleh Andar Lumbantobing. Jakarta: Yayasan Komunikasi Bina Kaih/OMF, 2002.

Hicks, L. "Melchizedek." Dalam The Interpreter's Dictionary of the Bible: An Illustrated Encyclopedia. Jilid. 3. Disunting oleh George Arthur Buttrick. New York: Abingdon Press, 1963.

Holladay, William L.'jv^m*." Dalam A Concise Hebrew and Aramic Lexicon of the Old Testament. Grand Rapids: William B Eerdmans Publishing Company, 1988.

Howard, David M. Kitab-kitab Sejarah dalam Perjanjian Lama. Malang: Gandum Mas, 2002.

Johnson, M. E. W. "Christ." Dalam Protestant Dictionary. Disunting oleh Charles H. H. Wright. Paternoster: Hodder and Stoghton, 1904.

Jones, Hywel R. "Keluaran.” Dalam Tafsiran Alkitab Masa Kini. Jilid. 1. Kejadian - Ester. Disunting oleh Donald Guthrie. Diterjemahkan oleh P. S. Naipospos. Jakarta: Yayasan Komunikasi Bina Kasih/OMF, 1995.

Kistimaler, Simon J. "Melchizedek." Dalam Who's Who in the Bible. Disunting oleh Paul D. Gardner. Grand Rapids: Zondervan Publishing House, 1995.

Kitchen, K. A. "Musa.” Dalam Ensiklopedi Alkitab Masa Kini. Jilid. 2. Disunting oleh H. A. Oppusunggu. Diterjemahkan oleh M. H. Simanungkalit. Jakarta: Yayasan Komunikasi Bina Kasih/OMF, 2002.

Ladd, George E. A Theology of the New Testament. Grand Rapids: Wm. B. Eermans, 1981. 
Marantika, Chris. Doktrin Keselamatan dan Kehidupan Rohani. Disunting oleh Mayan Marbun. Yogyakarta: Iman Press, 2002.

Marantika, Chris. Masa Depan Dunia Ditinjau dari Sudut Alkitab: Eskatologi. Disunting oleh Mayan Marbun. Yogyakarta: Iman Press, 2004.

McClintock John dan James Strong. "Melchiz'edek." Dalam Cyclopedia of Biblical Theological Ecclesiastical Literature. Jilid. 6. Me-New. Grand Rapids: Baker Book House, 1981.

Oswalt, John N.’jv^m*." Dalam New International Dictionary of Old Testament Theology \& Exegesis. Jilid. 2. Disunting oleh Willem A. VanGemeren. Carlisle, UK: Paternoster Publishing, 1997).

Owens, John Joseph."Genesis." Dalam Analytical Key to the Old Testament. Jilid. 1. Genesis - Joshua. Grand Rapids: Baker Book House, 1989.

Reed, Carl. Diktat Kuliah: Kamus Sementara Bahasa Ibrani-Bahasa Indonesia. Sem. IV, 2007.

Ross, Allen P. "Genesis." Dalam The Bible Knowledge Commentary: Old Testament. Disunting oleh John F. Walvoord dan Roy B. Zuck. Wheaton: Victor Books, 1973.

Ryrie, Charles C. "Yesus Kristus Tuhan Kita." Dalam Teologi Dasar: Panduan Populer untuk Memahami Kebenaran Alkitab. Jilid. 1. Prolegomena-Yesus Kristus Tuhan Kita. Diterjemahkan oleh Ratri Kumudawati. Yogyakarta: Andi, 2004.

Ryrie, Charles C. "Yesus Kristus Tuhan Kita." Dalam Teologi Dasar: Panduan Populer Untuk Memahami Kebenaran Alkitab. Jilid. 2. Keselamatan - Peristiwa-peristiwa Yang Akan Datang. Diterjemahkan oleh Ratri Kumudawati. Yogyakarta: Andi, 2004.

Sailhamer, John H. "Genesis." Dalam The Expositor's Bible Commentary. Jilid. 1. Genesis-Deutoronomy. Disunting oleh Frank H. Gaebelein. Grand Rapids: Zondervan Publishing House, 2000.

Swift, C. E. Graham."Markus." Dalam Tafsiran Alkitab Masa Kini. Jilid. 3. Matius-Wahyu. Disunting oleh Donald Gutrie dan lainnya. Diterjemahkan oleh Harun Hadiwjono. Jakarta: Yayasan Komunikasi Bina Kasih/OMF, 1996. 
Thayer, Joseph Henry. "Melcisedevk." Dalam Greek English Lexicon of the New Testament. New York: American Book Company, 1886.

Thiessen, Henry C. Teologi Sistematika. Malang: Gandum Mas, 2003.

Towns, Elmer L. Nama-nama Allah: Mengungkapkan Rahasia Namanama Allah dalam Perjanjian Lama untuk Menolong Anda Mengenal Dia secara Lebih Mendalam. Diterjemahkan oleh Lee Roy Robertson dan Hariyono. Yogyakarta: Andi, 2003.

Unger, Merrill F. 'Messiah." Dalam Unger's Bible Dictionary. Chicago: Moody Press, 1976.

Walker, W. L."Promise." Dalam The International Standard Bible Encyclopaedia. Jilid. 4. Naarah-Socho. Disunting oleh James Orr, John L. Nuelsen dan Edgar Y. Mullins. Grand Rapids: Wa. B. Eermands Publishing, 1981.

Wenham, Gordon J. "Genesis." Dalam Word Biblical Commentary. Jilid. 1. Genesis-Ruth. Disunting oleh David H. Hubbard, Glenn W. Baker, John D. W. Watt. Dallas: Word Book Publisher, 2001.

Woude, A. S. van der. "Christos." Dalam Theological Dictionary of the New Testament. Jilid. 1. Disunting oleh Geoffray W. Bromiley. Grand Rapids: William B. Eerdmans Publishing Company, t.t.

Yates, Kyle M. "Kejadian." dalam Tafsiran Alkitab Wycliffe. Jilid. 1. Kejadian-Ruth. Disunting oleh Charles F. Pfteffer dan Everett F. Harrison. Malang: Gandum Mas, 2004. 